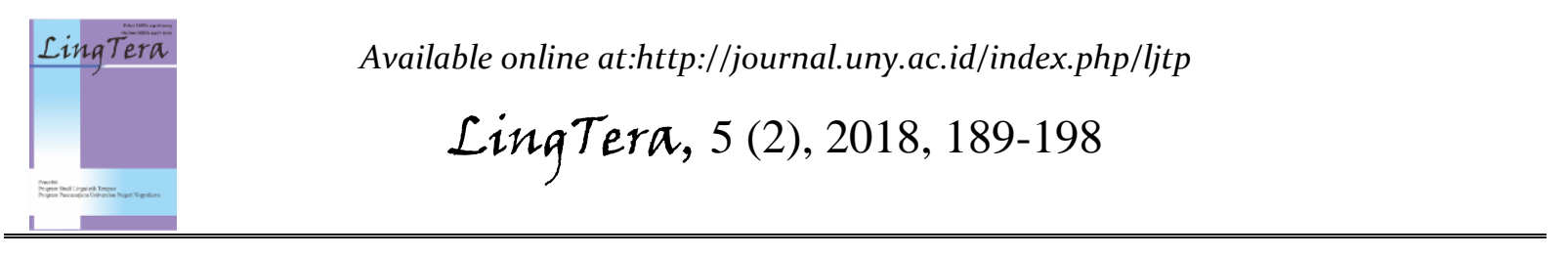

\title{
The effectiveness of using video and pictures in teaching writing hortatory exposition text
}

\author{
Adhan Kholis \\ Department of English Language Education, Universitas Nahdlatul Ulama Yogyakarta. \\ Jalan Lowanu No.47, Sorosutan, Umbulharjo, Kota Yogyakarta, 55162, Indonesia \\ Coresponding Author. E-mail: adhank74@gmail.com \\ Received: 28 August 2017; Revision: 19 September 2018; Accepted: 25 December 2018
}

\begin{abstract}
This study aimed to find out the differences in the students' achievement in writing the hortatory exposition text among the students taught by using video, pictures, and the lecturing method with the genre-based approach.This study was quasi-experimental research with the pretest and the posttest design. The sample consisted of grade eleven students of majoring science comprising three classes chosen by cluster random sampling. Two classes were for the experimental groups taught using video and pictures and the control group taught using the lecturing method. The data were collected using the test of writing. The validity established was the content validity, while the reliability used was interrater. Analysis of covariance (ANCOVA) was used to analyze data. The results of the study had shown that there were the significant differences between the experimental and the control groups where the use of video was the most effective media in teaching writing.
\end{abstract}

Keywords: media, teaching writing, hortatory exposition text, genre-based approach

How to Cite: Kholis, A. (2018). The effectiveness of using video and pictures in teaching writing hortatory exposition text. LingTera, 5(2), 189-198. doi:https://doi.org/10.21831/lt.v5i2.15490

https://doi.org/10.21831/lt.v5i2.15490

\section{INTRODUCTION}

Today, writing is regarded as a troublesome skill among the English skills namely listening, speaking, and reading. It is the mental work of inventing ideas, thinking about how to express them, and organizing them into statements and paragraphs that will be clear to a reader (Nunan, 2003, p. 88). It demands learners to think more critically in expressing ideas to be generated in a written form. Moreover, writing involves grammatical competence, vocabulary, diction, organization, and language use. Different with speaking, in writing, learners need much time in producing words. When writing, learners have more time to think rather than they do in oral activities. Learners can go through what they know in their minds, and even consult dictionaries, grammar books, or other reference materials to help them (Harmer, 2004, p. 31).

According to Harmer (2004, p. 31), writing has always formed part of the syllabus in the teaching of English. It indicates that writing should be taught in teaching and learning processes in the classroom. Nowadays, in teaching writing, most teachers just focus on explaining materials rather than engaging learners to do writing practically making them become passive in learning to write. Many teachers just ask learners to write down a sentence directly without any intensive helps such as giving building the context toward the topic just making learners difficult to start writing. Because students are language learners not writers, teachers should guide them intensively by providing some interventions and more feedbacks in development of writing skills (McDonough, Shaw, \& Masuhara, 2013).

Writing is a complex skill should be learnt by learners through teaching and learning processes in the classroom. In teaching writing, there are two roles of teachers in teaching namely as a motivator and a resource. Firstly, teachers as a motivator means that teachers should create the right conditions for generating ideas, persuading them the beneficial of the activity, and encouraging them to make as much effort as possible for maximum benefit (Harmer, 2001). Then, teachers should become a good resource for them during writing. Teachers must tell learners what are available and be prepared to look at their work as 


\section{LingTera,5 (2), 2018 - 190}

Adhan Kholis

it progresses, guiding them and giving advice before they start doing writing activity. Indeed, teachers can be able to be as a feedback provider. While learners have some difficulties in writing, a role of teachers here is very important, because learners still can't write by themselves without any helps from teachers. Teachers should also evaluate the students' writing.

Evaluating here means that teachers want to know learners' achievement in writing in the classroom. Teachers can conduct assessment before doing evaluating. Assessment is one of teachers' efforts in evaluating and knowing the students' writing skill. It can be also regarded as the giving feedbacks toward what learners have done in writing activity. Assessment is very important for teachers to know the ability of learners' writing. Moreover, teachers should use writing rubric in giving scores. To do assessment, teachers must consider some criteria or aspects of language.

In writing processes, most learners spend much time in imitating models rather than expressing their own ideas creatively and effectively. Learners are difficult to start writing some words even sentences. Learners have no ideas to be expressed in a written form. For instance, the learners' ability to write down exposition or persuasive text is far from expectation. Learners still have difficulties in giving some arguments and reasons related to the topic and issues given by the teacher. Exposition text belongs to the arguing text involving reasoning, evaluation, and persuasion. It is also a text type clearly focusing learners on the purpose of argument; that is, putting forward a viewpoint and providing evidence to support it (Knapp \& Watkins, 2005, p. 191). Here, this text demands learners to use their minds more in giving arguments and reasons toward the problems. Learners are still confused toward what they should write in the first line in giving arguments.

In relation to those problems, it is very urgent that teachers facilitate learners in learning to write optimally in order to make them easy to write down words even sentences. Teacher can apply instructional media in learning to write such as video and pictures. Since there are no best methods in language teaching, the existing of media is expected to be able to give more contribution in teaching English and to solve the problems regarding teaching and learning processes.

There are several definitions of media proposed by some experts. According to Heinich,
Molenda, Russel, \& Smaldino (2002, p.10) media refers to a channel of communication. It is derived from Latin word meaning "between" denoting anything carrying some information between sources and receivers including video, television, diagrams, printed materials, computers, and instructors. Those all are considered as media when they carry messages with an instructional purpose. The purpose of media is to facilitate communication. Media, the plural form of the word medium, are something that lies in the middle (between two parties) or a tool (Anitah, 2012, p.1). Meanwhile, Gerlach and Ely (1971) passing Arsyad (2011, p.3) says that media are understood as an outline of the human, material or events establishing the conditions making learners able to acquire the knowledge, skills, and attitudes. Media can be a form of audio, visual, and audio-visual.

The presence of media in teaching writing can stimulate learners to be more active and enthusiastic in learning. Picture books, film, still images, graphic novels and computer games can be a rich source for imaginative writing, offering models of settings, character and plot as scaffolds (Bearne \& Wolstencroft, 2007, p. 45). In using a video, learners are seeing the results of writing, not just reading or hearing them as in print and radio (Garrand, 2006, p. 35). The roles of visuals are also to provide concrete reference for ideas. Harmer (2001, p. 135) states that teachers sometimes use pictures for creative writing. Teachers may allow learners to invent a story using at least three of the images in front of them (on cue cards, for instance). Pairs of pictures in sequence provide for a variety of guided and free writing exercises (Raimes, 1983, p. 36).

Video and pictures are important to be applied by teachers in teaching writing hortatory exposition text. Both media ease teachers in explaining materials and make learners enthusiastic and motivated in learning to write. Video gives sensory stimuli to learners. The use of media should be considered and supported by language teachers in order to make teaching and learning processes become comfortable in practice. In this $21^{\text {st }}$ century, the notion of media has also become familiar in language teaching. Teachers are demanded to teach creatively using technology in conveying materials rather than just to explain more in front of class. From this, the ideas to use media in teaching writing should be stressed by teachers in the classroom.

Learning writing or learning to write is an activity requiring learners to learn how to become 
master in writing. Learning to write is easier if learners are engaged in authentic writing activities requiring learners to express their thoughts and ideas (Johnson, 2008). In this case, learners will be dealt with both skills namely composing and transcription skills. Firstly, composing skills includes the processes of writing itself including pre-writing, editing, re-drafting, and publishing. In this case, learners learn about the steps of writing. Secondly, transcription skills consist of micro skills in writing including punctuation, spelling, capitalization, and handwriting.

Writing in the classroom is different from writing in everyday life requiring people to write freely based on their experience in their life such as writing for diary entries. In writing, especially in the classroom, learners are demanded to work on writing skills such as academic study, examination preparation, and the like (Scrivener, 2005). However, here, teachers should remember that learners are language learners not as a writer; therefore, they must be guided in learning by helping them as much as possible providing some interventions and feedbacks in development of writing skills (McDonough, et al., 2013). It means that, in learning to write in the classroom, teachers cannot let them without giving some supports and feedbacks, because they are learners in nature.

Writing in the classroom, teachers should provide an environment for writing at least three main stages of (1) gathering ideas: pre-writing and planning, (2) working on drafts, and (3) preparing the final version (McDonough et al., 2013, p. 193). In this case, firstly, teachers can ask learners to collect their ideas before writing. Secondly, learners can start writing by making drafts in order to make easier for them in writing later. Finally, they can prepare their writing to be published by editing and revising the content and the structures.

Writing is important for language learners because of three reasons including (1) writing is vital skill for academic success (2) writing can be effective tools for the development of academic language proficiency (3) writing allows learners to raise their awareness of knowledge gaps (Warschauer, 2010).

Genre-based approach, also called textbased instruction, sees communicative competence as involving the mastery of different types of texts. Text here is used in special sense to refer to structured sequenced of language used in specific contexts in specific ways (Richards, 2006, p.36). It is also produced in, and determin- ed by, social context. Therefore, it is possible to identify the social elements in the structure and grammar of individual texts (Knapp \& Watkins, 2005).

This approach can be implemented in language teaching because of three assumptions about language learning as follows: (1) learning language is a social activity, (2) learning occurs more effectively if teachers are explicit about what is expected of students, and (3) the process of learning language is a series of scaffolded developmental steps which address different aspects of language (Feez \& Joyce, 1998, p.24).

From statements above, it can be said that language is taught as a social function not as a subject matter. It means that language occurs in social activity enabling learners to learn contexts. They meet many text types in a different form. In genre-based approach, the language knowledge is also focused on a social purpose where the most viewpoints are addressed to readers not writers (Rahman, 2011).

The content of genre-based approach in language teaching exactly consists of text-types. However, the syllabus also usually specifies other components of texts such as grammar, vocabulary, topics, and functions. Therefore, it is called a type of mixed syllabus, one which integrates reading, writing, and oral communication, and which teaches grammar through the mastery of texts rather than in isolation (Richards, 2006, p. 37). In this case, the syllabus of this approach is the mixture by integrating the four English skills and microskills of language.

The cycle of teaching and learning activities in the genre-based approach comprises a number of stages which a teacher and learners go through; therefore, learners gradually gain independent control of a particular text-type. Each stage has different activities in practice. The following stages below show the steps of teaching and learning process in genre-based approach as follows (Feez \& Joyce, 1998, pp. 28-31).

Hortatory exposition text is one of texttypes in English should be learnt by learners in formal education today. It belongs to the arguing text involving reasoning, evaluation, and persuasion. Hortatory exposition text is a text type clearly focusing learners on the purpose of argument; that is, putting forward a viewpoint and providing evidence to support it (Knapp \& Watkins, 2005, p. 191). It means that hortatory exposition requires learners to give some arguments related to the topic or problems stayed in the text. Hortatory exposition text is also a text 


\section{LingTera,5 (2), 2018 - 192}

Adhan Kholis

representing writers' efforts to have the addressee do something or act in certain way. It also belongs to persuasive text. Persuasive text can be a form of letters, web pages, formal speeches, essays, sermons, reports, and testimonials (Mills $\&$ Dooley, 2014). In a persuasive essay, learners can choose the most favorable evidence, appeal to emotions, and use style to persuade readers (Hillocks, 2010). This text also has generic structures beginning with a clearly stated thesis. Thesis contains a topic and the position of the writer. It is also followed by the argument stage. Sometimes, thesis only consists of one sentence stating the topic will be discussed in body. The second part in hortatory exposition text is argument. It contains of learners' arguments regarding with the topic elaborated in the first stage. Here, learners are demanded to think more critical in facing the problems stated in text. They can give some agreements and disagreements based on their point of view. The final stage of the hortatory exposition is the recommendation, where the thesis is reiterated. In this stage, learners propose advice and suggestion based on the problems from the thesis. In more complex texts, a summary is also given at this point.

It is very important to present media in teaching writing in the classroom especially teaching writing hortatory exposition text to help students ease to write text and enjoy in learning to write. Media today can facilitate students in learning and thinking critically. Against this background, this study is conducted to find out the differences in the students' achievement in writing hortatory exposition text among the students taught by using video and pictures with genre-based approach and those taught by using lecturing method. Also, it is conducted to know whether the using of video and pictures gave more contribution to the learning of writing hortatory exposition text than lecturing method.

\section{METHOD}

This study was an experimental research in the form of quasi-experimental design with pretest and posttest approach. The reason of a quasi-experiment is the inability to randomly assign participants to some treatment conditions corresponding to a level of an independent variable (Dunn, 2001, p.74). The researcher decided to select the non-equivalent control group design. It meant that both the experimental and the control group had not been equated by randomization. This study was conducted to find out a significant difference among three methods namely the use of video, pictures, and lecturing method with genre-based approach in teaching writing hortatory exposition text.

This study took place at the senior high school located in Ponorogo, East Java province, carried out from March till April 2017. The population consisted of grade eleven students of MA Darul Huda. The sample consisted of grade eleven of majoring science comprising three classes chosen by cluster random sampling. The number of students was 72 students where each class consisted of 24 students.

In this design, there were three groups comprising two experimental groups and one control group chosen by random sampling. Then, these groups were given a pretest to know the first situation and condition whether any differences between the experimental and control group. The experimental group members receive the treatment, while members in the control group either receive the traditional approach (e.g., teaching method) or do not receive any treatment (Ravid, 2011, p.7). Here, in the experimental group, the teachers gave the treatments namely the use of video and pictures with genre-based approach, while the control group was carried out by using lecturing method. After conducting treatments, the teacher then gave the posttest in the same writing test.

The data was in the form of scores. The technique for collecting data was the test of writing. Data collection technique used in this study was a test. Collecting data on the experimental study was done by giving the writing test of hortatory exposition text. This test was used to know the learners' ability in learning of writing. The learners should write hortatory exposition text in the form of essay. The learners must write two types of writing namely free and guided writing. Giving tests performed twice, those were early stage or pre-test done before getting treatment, and the final test or post-test performed after the treatment. This study used data collection technique done by test method such as the assignment of writing used to measure the achievement of standards of competence by using video and pictures as defined in the standard of competence of graduates. Based on the research design, the pretest was conducted simultaneously before being given treatment. The posttest also carried out simultaneously after being treated.

The research instrument used in this study was the instrument of learners' ability in writing hortatory exposition text. The instrument used to collect data of learners' writing skills was 
assessment criteria of hortatory exposition text. With the instrument, the learners were tested to get a score. The score was then collected and used for analysis. Assessment criteria contained the factors relating to the assessment of writing as proposed by Jacobs. Assessment criteria of writing ability to be determined based on the elements related to writing namely contents, organizations, vocabularies, language use, and mechanic.

Writing test was in the form of essay. The teacher asked the learners to write down hortatory exposition text. In the test items, there were two types of writing test namely guided and free writing. In the guided writing, the learners would be helped with the clear guidance, whereas in the free writing, the learners freely wrote down some arguments and reasons related to hortatory exposition text.

In scoring the learners' writing, the teachers used rubric taken from Jacobs's theory comprising five components of writing namely content, organization, vocabulary, language use, and mechanics. The reason why the teachers used this rubric for assessing the learners' writing was because of comprehensive aspects of rubric.

The instrument used was the instrument of learners' ability in writing hortatory exposition text. The instrument validity was content validity, whereas the reliability of instrument was interrater technique. In scoring the learners' writing, the researcher used rubric proposed by Hughes containing five components completed by descriptors.

In analyzing data, the researcher used descriptive statistics consisting of mean, median, mode, range, and standard deviation. Moreover, inferential statistics namely analysis of covariance (ANCOVA) with the significance level $5 \%$ or 0.05 computed by using SPSS program version 22 was also used to draw the conclusion.

In the descriptive statistics, the researcher used the mean as a measure of center, because both pretest and posttest data, there were no extreme scores. It meant that the scores reflected every score in the distribution. The mean represented any of 24 scores in the distribution. Moreover, the researcher used the mean as the measure of center because all data were in the normal distribution. The detail results of computing the descriptive statistics in SPSS Program version 22 .

The data analysis technique used in this study was a parametric statistic technique using analysis of covariance (ANCOVA) computed by using SPSS Program version 22. This study only focused on knowing the effects of treatments toward the experimental class namely the using of media in teaching writing hortatory exposition text. The researcher used the inferential statistics for analyzing the data of sample and the results would be applied and generated in the population. It meant that the inferential statistics were used for drawing conclusions and making inferences about the population. Also, this was used to compare among three groups on the independent variables. Based on the results of the data, the scores of among three groups rose from pretest to posttest. In computing ANCOVA, the pretest data were as the covariate variables. In the inferential statistics, the researcher used the posttest means to compare three groups. The data on the covariate and the dependent variable were used to compute the adjusted means on the dependent variable. The detail results of computing the inferential statistics in SPSS Program version 22 could be seen in the appendix six.

\section{FINDINGS AND DISCUSSION}

The findings were derived from the results of test of students' writing. The data used were from pretest and posttest. In knowing the students' average scores, the researcher used the mean as the centre of measure, whereas in drawing the conclusion, the researcher used ANCOVA.

Table 1. The Mean Differences of Three Classes

\begin{tabular}{cc}
\hline Treatments & Mean Scores \\
\hline Lecturing Method & 67.2083 \\
Video & 81.4167 \\
Pictures & 74.3750
\end{tabular}

Based on the table presented on Table 1 above, the highest scores among three methods were the video where the value of the mean was 81.4167 , while the lowest scores were lecturing method where the value of the mean 67.2083. This showed that among three methods used in teaching writing hortatory exposition text, the most effective media were the video.

The research result from Table 1 was similar to TESOL research result conducting the experiment research where the results of the study showed that using audio-visual aids in the classroom, teachers can teach languages making the class interesting. Different visuals bring variation in teaching which are helpful to draw the attention of the students toward the lessons. For example, if the language teachers use different pictures related to the lesson of the class, 


\section{LingTera,5 (2), 2018 - 194}

Adhan Kholis

the classes become lively as well as learners get some schemata of the topic. It is always better to have something visuals in front of the students so that they can understand the lesson well.

Furthermore, the study referred to Thesis written by Rizkiyah (2014) from UM conducting Classroom Action Research (CAR) also gave the same result where the research results showed that the using of Youtube videos can increase the students' ability in writing hortatory exposition text. The students' percent reaching the higher value from $15.8 \%$ in the preliminary study can get $100 \%$ in Cycle 1 .

Based on the data presented on the Table 2 above, the value of sig was .000. If the value of sig was lower than 0.05 so that Ho was rejected and $\mathrm{H} 1$ was accepted. This can be seen on the term of media. It can be concluded that there was a significant difference in the students' achievement in writing hortatory exposition text among the students' taught by using video, pictures, and lecturing method.

Based on the Table 2, it was obvious from the significance value where the value was lower than 0.05 . The value of sig was 0.000 showing that it was lower than the value of alpha 0.05. Related to the requirement explained before stating that if the sig. value is lower than significance, therefore, Ho was rejected. Thus, in this case, there was a significant difference among three methods applied in teaching writing toward students' achievement in writing hortatory exposition text, because the value of sig. was 0.000 . In other word, media seemed to have significant effects on the students' achievement in writing hortatory exposition text. It should also be noted that the total amount of variation to be explained was 7370.000 (Corrected Total), of which the experimental manipulation accounted for 2426.305 units (SSm), whereas 4772.571 was unexplained ( $\mathrm{SSr}$ ). For the pretest or the covariate variable, the sig value was 0.119 higher than 0.05 . It meant that there was no effect given by the pretest toward the dependent variable namely the students' achievement in writing.

Based on the computing results in SPSS Program version 22 presented on the Table 3, it can be seen that the probability or significance was 0.000 lower than significance level $5 \%$ or 0.05 . Based on the decision had been determined before stating that if the sig is lower than alpha $(\alpha)$, so that Ho is rejected or $\mathrm{H} 1$ is accepted, it can be concluded that there was a significant differrence between the using of video and lecturing method toward the students' achievement in writing hortatory exposition text.

This result was same with the Novita research conducting the experiment research where the result showed that the using of video gave effects to students' achievement in writing descriptive text. Moreover, video was more effective than conventional teaching proved by the value of mean score (72.44) higher than conventional teaching (61.18).

Also, the journal proposed by Ismaili from South East European University (SEEU) conducting experimental study showed that there were significant differences between the experimental and control groups of students on integrated skills where movies attracted students' attention, presented language in a more natural way that found in course-books.

To find out the significant difference between pictures and lecturing method, it can be seen that the probability or significant was 0.017 with significance level $5 \%$ or 0.05 . It was definetely lower than the value of alpha $(\alpha)$. Based on the decision had been determined before stating that if the sig is lower than alpha $(\alpha)$, so that Ho is rejected or $\mathrm{H} 1$ is accepted, it can be concluded that there was a significant difference between the using of pictures and lecturing method toward the students' achievement in writing hortatory exposition text.

This result was supported by the Ariningsih (2010) research from UNS conducting Classroom Action Research (CAR). Based on the results of data analysis, the research findings were: (1) the picture series was more effective than translation to teach writing for the seventh grade students of junior high school, (2) the writing skill achievement of the students having high motivation was better than that of those having low motivation, and (3) there was an interaction between teaching techniques and learning motivation. Based on these research findings, it can be concluded that picture series was an effective technique used to improve the writing skill of the seventh grade students of SMPN 1 Tanjunganom, Nganjuk.

Indeed, the result was similar to Adawiyah (2006) research conducting Classroom Action Research (CAR) where the study showed that there was an enhancement of the students' achievement after given a treatment by using pictures. Students taught by using visual media have a high achievement in writing composition text rather than those taught by using conventional media. 

LingTera,5(2), 2018 - 195

Adhan Kholis

Table 2. The Computing of ANCOVA

\begin{tabular}{lccccc}
\hline \multicolumn{1}{c}{ Source } & Type III Sum of Squares & Df & Mean & F & Sig. \\
\hline Corrected Model & 2597.43 & 3 & 865.810 & 12.3 & .000 \\
Intercept & 20491.3 & 1 & 20491.2 & 291 & .000 \\
Pretest & 174.846 & 1 & 174.846 & 2.49 & .119 \\
Media & 2426.31 & 2 & 1213.15 & 17.3 & .000 \\
Error & 4772.57 & 68 & 70.185 & & \\
Total & 405202 & 72 & & & \\
Corrected Total & 7370.00 & 71 & &
\end{tabular}

Table 3. Multiple Comparisons of ThreeMethods

\begin{tabular}{cclcc}
\hline \multicolumn{2}{c}{ Treatments (I) } & \multicolumn{1}{c}{ Mean Difference (I-J) } & Std. error & Sig. \\
\hline \multirow{2}{*}{ LM } & Video & $-14.2083^{*}$ & 2.44441 & 0.000 \\
& Pictures & $-7.16667^{*}$ & 2.44441 & 0.017 \\
\multirow{2}{*}{ Video } & LM & $14.20833^{*}$ & 2.44441 & 0.000 \\
& Pictures & $7.04167^{*}$ & 2.44441 & 0.020 \\
\multirow{2}{*}{ Pictures } & LM & $7.16667^{*}$ & 2.44441 & 0.017 \\
& Video & $-7.04167^{*}$ & 2.44441 & 0.020
\end{tabular}

Furthermore, this result was supported by International journal written by Allen showing that the use of audio-visual aids can help students understand the deep meaning of a topic and realize similarities and differences between eachtopic.

To reveal that whether the use of video is more effective than pictures, it can be seen that the probability or significant was 0.020 with significance level $5 \%$ or 0.05 . It was definitely lower than the value of alpha $(\alpha)$. Based on the decision had been determined before stating that if the sig is lower than alpha $(\alpha)$, so that Ho is rejected or $\mathrm{H} 1$ is accepted, it can be concluded that there was a significant difference between the using of video and pictures with genre-based approach toward the students' achievement in writing hortatory exposition text.

The table 3 above presented the multiple comparisons among three methods. This was done to find out the differences from each class. The mark star noticed that there were significance differences on each method. Indeed, the value of sig showed that there were significant differences because the sig lower than 0.05. Based on the data shown above, there were some differences on each method. Firstly, the use of video was more effective than lecturing method where the mean difference was $14.20833^{*}$. Secondly, the use of pictures was more effective than lecturing method where the mean difference was 7.16667*. Thirdly, the use of video was more effective than pictures where the mean difference was 7.04167*.

This section presented the discussion of research finding proposed before mainly focused on the hypotheses testing. This study endeavored to know the effectiveness among three methods in teaching writing namely the using of media including video and pictures, and lecturing method toward the students' achievement in writing hortatory exposition text to grade eleven students of MA Darul Huda Ponorogo in academic year 2016/2017 used both in the control and experimental class. It was also definitely to know the students' scores in writing. Therefore, here, to obtain the data, the researcher used a test only as a tool to collect the data. The test used was test of writing hortatory exposition text. The reason why the researcher decided to select hortatory text as the text used in writing was because it was taught in the semester two in grade eleven students. The writing test comprised two types including guide and free writing. The purpose of combining two types was exactly to get learners' scores in writing more valid. It meant that the researcher wanted to know the learners' writing both in guide and free writing whether they can do tasks in the different types. In the guided writing, there were some instructions and guidance that can be used by the learners before writing hortatory exposition text. The guidance formed the sentences should be continued by regarding the topic sentences. In this case, the learners just continued some sentences, but in the same topic. In the contrary, in the free writing, the learners were demanded to write freely based on the topic proposed by the teacher. The topic was about the using of social media in internet mainly about the abuse of it. The steps should be done by the learners were to read some topic first given by the teacher in 


\section{LingTera,5 (2), 2018 - 196}

Adhan Kholis

Indonesia language. After that, the learners can start writing hortatory exposition freely appropriated with their knowledge toward social media.

In this study, the researcher just used a test as a tool to collect the data, because the researcher just wanted to know the learners' writing. In analyzing the data, the researcher used two techniques namely descriptive sand inferential statistics. Both of them had the different purposes where descriptive statistics was applied to know the learners' average scores in writing hortatory exposition text including mean, median, mode, standard deviation, and minimum and maximum value, while inferential statistics was used to know the significant differences among three methods and to prove the four hypotheses. After collecting the data, then, the researcher analyzed it using analysis of covariance (ANCOVA) with SPSS Program version 22. Based on all computing had done before in analyzing processes, the results showed that among three methods gave the different effects toward the students' achievement in writing hortatory exposition text. The mean or average of three methods was shown in the following Table 4.

Table 4. Mean Scores

\begin{tabular}{ll}
\hline Treatment & Mean Scores \\
\hline Lecturing Method & 67.2083 \\
Video & 81.4167 \\
Pictures & 74.3750 \\
\hline
\end{tabular}

The Table 4 showed that among three methods used in teaching writing, the most effective media was video with the mean scores 81.4167. The next effective media was pictures with the scores 74.3750 , and the last one was lecturing method with the score 67.2083. Also, it can be concluded that both the control and experimental group were different where the experimental class taught by using media more gave contribution in teaching writing rather than the control class taught using lecturing method. Those results were also same with testing results of hypothesis in analysis of covariance (ANCOVA) showing that there was a difference in the students' achievement in writing hortatory exposition text among students taught by using video, pictures, and lecturing method. Those had been proved by using ANCOVA in SPSS Program version 22 scoring the probability value 0.000 that was lower than significance level of alpha $(\alpha) 5 \%$ or 0.05 . Consequently, Ho was rejected and $\mathrm{H} 1$ was accepted there was a significant different among three methods in teaching writing of hortatory exposition text. The differences of students' achievement in writing were definitely affected by the using of media with the genre-based approach. It would be different when the teacher just taught using lecturing method without any media also.

The second hypothesis tested the effectiveness of using video and lecturing method in teaching writing hortatory exposition text. The results showed that the using of the video was more effective than lecturing method. This was based on the mean both methods where video got scores $(81.42>67.21)$ higher than lecturing method. Then, those data were strengthened by testing results of ANCOVA (Scheffe test) showing that the probability or significance value 0.000 lower than significance level $5 \%$ or 0.05 . Therefore, Ho was rejected and $\mathrm{H} 1$ was accepted that the using of video was more effective than lecturing method in teaching writing of hortatory exposition text.

The third hypothesis tested the effectiveness of using pictures and lecturing method in teaching writing hortatory exposition text. The results showed that there was a significant difference both methods where the using of pictures was more effective than lecturing method. This was based on the mean scores where pictures got (74.38) higher than lecturing method just got (67.21). Moreover, those data were strengthened by testing results of ANCOVA (Scheffe test) showing that the probability or significance value 0.017 lower than significance level $5 \%$ or 0.05 . Therefore, Ho was rejected and H1 was accepted that the using of pictures was more effective than lecturing method in teaching writing of hortatory exposition text.

The fourth hypothesis tested the effectiveness of using both the using of video and pictures in teaching writing of hortatory exposition text. The results showed that there was a significant difference both media where the using of video was more effective than the using of pictures in teaching writing of hortatory exposition text to grade eleven students of MA Darul Huda Ponorogo. This was based on the mean scores where video got (81.42) higher than pictures just got (74.38). Moreover, those data were strengthened by testing results of ANCOVA (Scheffe test) showing that the probability or significance value 0.020 lower than significance level $5 \%$ or 0.05 . Therefore, Ho was rejected and $\mathrm{H} 1$ was accepted that the using of video was more effective than pictures in teaching writing of hortatory exposition text. These results were same with the 
research conducted by Falupi, Arifin, \& Novita (2013) conducting experimental research in Tanjungpura University, Pontianak concluding that the using of video was more effective than pictures in teaching writing of descriptive text. The means of video was 72.44 higher than means of pictures 61.18.

The researcher used the mean to describe the data of sample and did not want to make conclusion applied in the population where the sample was taken place. The researcher used data from pretest and posttest in computing mean. Both pretest and posttest scores, there were no extreme scores. Thus, the researcher decided to use the mean as the measure of center.

Another measure of central tendency was known as the median. It refers to the middle point of a distribution of scores that are ordered (Ravid, 2011, p.73). The median was actually a better measure of centrality than the mean if the data were skewed, meaning lopsided. The median took more information into account than the mode. Because the scores both pretest and posttest were not skewed, the researcher did not use the median as a measure of center.

From the above, it was clear that the most effective media used in teaching writing hortatory exposition text was the video. The video gave more benefits in leading and guiding the learners in learning to write persuasive text than pictures and lecturing method. The video gave the learners more stimulus and input. Also, through the video, the learners became more critical in giving responds toward the contents. Referring to Anthony (2006) states that video makes a good use of close-ups and communicates the body language of human expression, particularly the face, very effectively. From this, the learners can see some expressions existing in the video requiring them to focus on the content. Moreover, the learners can know the chronological or sequence based on the story or action in the video. Then, the video also gave motion and people's expression in nature different from pictures. Pictures just gave a silent visual not moving pictures. The lack of using pictures was there was no sequence or plot in the content. Thus, the learners were rather difficult to interpret the contents. In relation to learning to write, the video engaged the learners to express their minds critically to be generated in the written form. When watching the video, the learners looked at what the video broadcasted and thought more regarding the content. It was appropriate with persuasive text where the nature of text was giving arguments and responds toward problems. From this, the learners were demanded to give arguments clearly when they write persuasive text. This was different from lecturing method where the learners were not guided by any media in learning to write. The teachers just explained materials more in front of class. Therefore, the learners were bored and not motivated in learning to write.

Based on findings presented before, the existing of media in teaching writing hortatory exposition gives more beneficial for learning to write. The results showed that the most effective media in teaching writing were video.

Among three methods had the different quality in affecting the students' achievement in writing. Media with more sensory stimuli were more effective than those with less sensory stimuli. The more sensory stimuli the media had the more effective the teaching would be.

Video gave more motion than pictures. In practice, video contained more sensor stimuli like audio and visual than pictures just containing visual effects. When the learners watched the video, their attention toward the content was bigger than looking at pictures.

By watching video in the classroom, learners can think more and give respond toward the content of video. Video gives stimulus to learners and directions where learners want to do. The roles of visuals are also to provide concrete reference for ideas. It can motivate learners by attracting, and holding their attention, and even generating emotional response.

Indeed, in practice, the strength of video is that it can give motion, expression, self-learning, and emotion, because learners can look at some people's expressions, gestures, and mimics in the video. Learners can watch people's motion doing something in video. Learners can focus on watching video making them become critical in thinking. Furthermore, video contains of sounds that can make learners study the sentences in conversation or speech. They can know the plots of conversation or speech easily. From this, when learners watch video in the classroom, they are able to catch ideas from video's contents to be expressed by using spoken and even written language.

\section{CONCLUSIONS}

The conclusions in this study are drawn from the findings and discussions presented previously aiming at answering the research questions of this study. Firstly, there is a significant 


\section{LingTera,5 (2), 2018 - 198}

Adhan Kholis

difference in the students' achievement in writing hortatory exposition text among the students taught by using video, pictures, and lecturing method. It can be seen from the value of sig (0.000) lower than 0.05 on Table 2. Secondly, there is a significant difference in the students' achievement in writing hortatory exposition text between the students taught by using video and those taught by using lecturing method where the using of video is more effective than lecturing method. Thirdly, there is a significant difference in the students' achievement in writing hortatory exposition text between the students taught by using pictures and those taught by using lecturing method where the using of pictures is more effective than lecturing method. Fourth, there is a significant difference in the students' achievement in writing hortatory exposition text between the students taught by using video and those taught by using pictures where the using of video is more effective than pictures.

\section{REFERENCES}

Anitah, S. (2012). Media pembelajaran. Surakarta: Yuma Pustaka

Arsyad, A. (2011). Media pembelajaran. Jakarta: Raja GrafindoPersada.

Bearne, E., \& Wolstencroft, H. (2007). Visual approaches to teaching writing. London: Paul Chapman Publishing.

Dunn, D. S. (2001). Statistics and data analysis for the behavioral sciences. New York: McGraw Hill.

Falupi, S. N., Arifin, Z., \& Novita, D. (2013). Teaching descriptive text writing by using video to junior high school students. Jurnal Pendidikan dan Pembelajaran, 2(3). Retrived from http://jurnal.untan.ac.id/index.php/jpdpb/a rticle/view/1363

Feez, S. \& Joyce, H. (1998). Text-based syllabus design. Sydney: AMES.

Garrand, T. (2006). Writing for multimedia and the web. Oxford: Elsevier.

Harmer, J. (2001). The practice of English language teaching. Essex, England: Longman.

Harmer, J. (2004). How to teach writing. Essex, England: Longman.
Heinich, R., Molenda, M., Russell, J. D., \&Smaldino, S. E. (2002). Instructional media and technologies for learning. New York: Merill Prentice Hall.

Hillocks, G. (2010). Teaching argument for critical thinking and writing: An introduction. English Journal, 99 (6), 2432

Johnson, A. P. (2008). Teaching reading and writing: A guidebook for tutoring and remediating students. Plymouth: The Rowman\& Littlefield Publishing Group, Inc.

Knapp, P., \& Watkins, M. (2005). Genre, text, grammar: Technologies for teaching and assessing writing. Sydney: UNSW Press.

McDonough, J., Shaw, C., \& Masuhara, H. (2013). Materials and methods in ELT: A teacher's guide. $3^{\text {rd }}$. Oxford: WileyBlackwell.

Mills, K., \& Dooley, K. (2014). Teaching persuasive texts: Building a language of evaluation through hedging and moderated intensification. Literacy Learning: The Middle Years, 22(3), 33-41.

Nunan, D. (2003). Practical English language teaching. New York: The McGraw Hill Companies.

Rahman, M. M. (2011). Genre-based writing instruction: Implications in ESP classroom. English for Specific Purposes World, 11(33), 1-9.

Raimes, A. (1983). Techniques in teaching writing. Oxford: Oxford University Press.

Ravid, R. (2011). Practical statistics. Plymouth: Rowman\& Littlefield Publishers, Inc.

Richards, J. C. (2006). Communicative language teaching today. Cambridge: Cambridge University Press.

Scrivener, J. (2005). Learning teaching: A guidebook for English language teachers. Oxford: Macmillan.

Warschauer, M. (2010). Invited commentary: New tools for teaching writing. Language learning \& technology, 14(1), 3-8. 